Arab Univ. J. Agric. Sci., Ain Shams Univ., Cairo, 13(2), 559 - 568, 2005

\title{
EFFECT OF BIOMPHALARIA ALEXANDRINA SNAILS INFECTED BY BACILLUS THURINGIENSIS KURSTAKI ON THREE SUCCESSIVE GENERATIONS OF SCHISTOSOMA MANSONI
}

[37]

\author{
Samia N. El-Bardicy ${ }^{1}$; Menerva M. Tadros ${ }^{1}$ and Sherif M. Hafez ${ }^{2}$
}

\begin{abstract}
The effect of infection of Biomphalaria alexandrina snails with Bacillus thuringiensis kurstaki on various stages of Schistosoma mansoni life cycle was studied for three successive generations. Thus, two groups of snails were exposed to a sublethal concentration of the bacteria $(0.08 \mathrm{gm} / \mathrm{L}$ water $)$ containing $32000 \mathrm{IU} / \mathrm{mg}$, for one week and to schistosome miracidia. One group was exposed to the miracidia before bacterial infection, while the other group to the miracidia after the bacterial infection. Cercariae produced from each group of snails were used to infect albino mice. The infection of snails and mice with the parasite was repeated for three generations of the parasite. In the first case, data obtained show that the schistosome infection rate of snails was considerably reduced being $60 \%, 18 \%$, and $66.6 \%$ versus $90 \%$, $92 \%$ and $90 \%$ in untreated control snails in the three generations of the parasite, respectively. Meanwhile, the mean prepatent period was extended being $29.1 \pm 4.3$ days, $33 \pm 1$ days and $38.5 \pm 2.5$ days versus 27 days in the control group. The number of worms recovered from infected mice showed reduction of $52 \%, 78.4 \%$ and $58.6 \%$, respectively. In the second case, the infection rate of snails was $40 \%, 16 \%$ and $73.7 \%$ for the three successive parasite generations and the prepatent period was $32 \pm 1$ days, $32 \pm 2.3$ days and $35 \pm 2.8$ days, respectively. The reduction percentage of the recovered worms was $34.8,73.6$ and 72.9 in the sccessive generations, respectively. The present results prove that infecting B.alexandrina snails with a sublethal concentration of $B$. thuringiensis kurstaki bacteria exhibits clear negative effect on the transmission of $S$. mansoni in three successive generations. So, it could be recommended to use $B$. thuringiensis kurstaki as a potential biocontrol agent against $S$. mansoni.
\end{abstract}

Key words: Biomphalaria alexandrina, Bacillus thuringiensis kurstaki, Schistosoma mansoni, Schistosome infection, Worm recovery

1-Medical Malacology Department, Theodor Bilharz Research Institute, Imbaba, Giza, Egypt .

2-Plant Protection Department, Faculty of Agriculture, Ain Shams University, Cairo, Egypt. 


\section{INTRODUCTION}

Old references show that Biomphalaria alexandrina, the snail host of Schistosoma mansoni in Egypt, had been widely distributed in the Nile Delta only (Barlow \& Munech, 1951), while recent publications show that this snail has invaded upper Egypt till Aswan (Heynman, 1978). It is known that snail control is the most promising method of supressing schistosomiasis transmission, and utilizing molluscicides has proved to be the single most effective agent of reducing snail population (Shiff, 1961). However, chemical means are hazardous from the environmental point of view. Using biological agents should have advantages over the chemical methods, being safer and more specific. One of these agents is bacteria which is specially pathogenic against the target snails (Madsen, 1992).

In this respect certain species and varieties of bacteria such as Vibrio, Pseudomonas, Citrobacter, Aeromonas, and Bacillus thuringiensis have been tested on some biological aspects of fresh water snails (Ducklow et al 1980 and 1981; Larget \& Barjac, 1981; Cheng, 1986; Madsen, 1992; Osman et al 1992; Singer et al 1994; El Emam et al 1996; El Emam \& Haroun, 1999). B. thuringiensis kurstaki was found to have a significant toxic effect on B.alexandrina snails and a concentration of this bacteria as low as $0.08 \mathrm{gm} / \mathrm{L}$ water has a considerable reducing effect on egg production of the snail and on its infection with S.mansoni (Gamal et al 2000).

The aim of the present work was to study the effect of infection of B. alexandrina snails with $B$. thuringiensis kurstaki on stages of the life cycle of three successive generations of $S$. mansoni. Expo- sure of snails to the bacteria was performed before and after infection of snails with the schistosome miracidia. This study should contribute to the evaluation of utilizing this variety of bacteria as a biocontrol agent against the present important snail vector of schistosomiasis.

\section{MATERIAL AND METHODS}

Laboratory produced Biomphalaria alexandrina snails of the same diameter (3-5 mm) and albino mice (CD1) were obtained from the Schistosome Biological Supply Program (SBSP), Theodor Bilharz Research Institute (TBRI), Egypt. The commercial bacteria Bacillus thuringiensis kuristaki (Ecotech bacteria) in the form of a powder containing 32000 IU/mg was obtained from the Plant Protection Institute, Ministry of Agriculture, Dokki.

One hundred snails were divided equally into two groups. Snails of one group were exposed to $S$. mansoni miracidia then after they were maintained for one week in two aquaria containing Ecotech bacteria water solution $(0.08 \mathrm{~g} / \mathrm{L})$ i.e. $2560000 \mathrm{IU} / \mathrm{L}$., 25 snails in $2 \mathrm{~L}$ of bacterial solution in each aquarium. Such concentration has been found to be sublethal to $B$. alexandrina snails (Gamal et al 2000). After that snails were washed carefully and transferred to clean dechlorinated water. The other group of snails was maintained in the same concentration of bacteria water solution for one week, then thoroughly washed with running declorinated water, and exposed to $S$. mansoni miracidia.

Exposure of snails of both groups to miracidia was in mass using 8-10 miracidia / snail for two hours. Only freshly hatched miracidia were used within one 
hour of hatching (Prah and James, 1977). Twenty-five snails were infected with $S$. mansoni miracidia without exposure to the bacteria to be used as control. Bacteria infected and control snails were maintained under standardized laboratory conditions (Liang, 1974). Starting from 26 days post infection, the surviving snails were examined individually twice weekly for cercarial shedding. The shedding snails were counted and separated in other aquaria. The produced cercarial suspension from both groups of snails were used to infect six albino mice. Each one was exposed by tail immersion technique to $80-100$ cercariae in $5 \mathrm{ml}$ of declorinated tap water at room temperature $\left(25 \pm 1^{\circ} \mathrm{C}\right.$.) for 2 hours.

Infection of snails and mice was repeated three times using the same procedures to produce three generations of the schistosome parasite. In each generation the snail infection rate and prepatent period of the parasite in snails were determined. Worms were recovered from the portomesenteric system of mice by the perfusion technique 45 days post infection and the mean recovery rate of worms was calculated in each case.

\section{RESULTS}

In the first case, in which the snails were exposed to Ecotech bacteria after being infected with $S$. mansoni miracidia, the results (Table, 1) indicate that the tested bacteria caused a considerable reduction in the infection rate of snails in the three parasite generations. The highest reduction $(80.4 \%)$ was recorded in the second generation. Meanwhile, the prepatent period of the parasite in snails was prolonged in the successive generations, being $29.1 \pm 4.3$ days, $33 \pm 1$ days and $38.5 \pm 2.5$ days, respectively, showing increasing change from the first (7.8\%), second $(22.2 \%)$ to the third (42.6\%) generations. In the second case in which exposing of snails to bacteria was performed before miracidial infection, the bacteria caused significant reduction (Table, 2) in the infection rate in the $1^{\text {st }}$ and $2^{\text {nd }}$ generations. While the reduction was much less in the $3^{\text {rd }}$ generation. The length of the prepatent period of the parasite in snails increased almost equally in the three generations of the parasite.

Comparing results of both cases, it appears that the infection rate of $B$. alexandrina with $S$. mansoni was more reduced in the first generation of the second case, and almost similar in the next two generations. The prepatent period was slightly longer in the $1^{\text {st }}$ case than the $2^{\text {nd }}$ one.

The cercariae produced from B. alexandrina snails exposed to bacteria before and after infection with $S$. mansoni miracidia, produced significantly less numbers of worms from the mice in the successive three generations (Tables $3 \& 4$ ) in comparison with those produced from the control group, without significant different between male and female worms. The difference in recovery rate of worms between the three generations of parasite and in both cases of bacterial infection is slight and insignificant.

\section{DISCUSSION}

Several reports are found in the literature on the impact of various spp. and strains of Bacillus bacteria on schistosome vector snails, showing different 
Table 1. Effect of infecting Biomphalaria alexandrina snails with Bacillus thuringiensis kurstaki after Schistosoma mansoni miracidial exposure on infection and intramolluscan development of the parasite in three successive generations

\begin{tabular}{|c|c|c|c|c|c|c|c|c|c|}
\hline \multirow[b]{2}{*}{ Parameter } & \multicolumn{3}{|c|}{ First generation } & \multicolumn{3}{|c|}{ Second generation } & \multicolumn{3}{|c|}{ Third generation } \\
\hline & Control & $\begin{array}{l}\text { infected } \\
\text { with } \\
\text { bacteria }\end{array}$ & $\begin{array}{l}\% \text { of } \\
\text { change }\end{array}$ & Control & $\begin{array}{l}\text { infected } \\
\text { with } \\
\text { bacteria }\end{array}$ & $\begin{array}{l}\% \text { of } \\
\text { change }\end{array}$ & Control & $\begin{array}{l}\text { infected } \\
\text { with } \\
\text { bacteria }\end{array}$ & $\begin{array}{l}\% \text { of } \\
\text { change }\end{array}$ \\
\hline $\begin{array}{c}\text { Number of } \\
\text { exposed snails }\end{array}$ & 25 & 25 & & 50 & 50 & & 30 & 30 & \\
\hline$\%$ of Infection & 90 & 60 & $(-33.3)$ & 92 & 18 & $(-80.4)$ & 90 & 66.6 & $(-26)$ \\
\hline $\begin{array}{l}\text { Mean prepatent } \\
\text { period (days) }\end{array}$ & 27 & 29.1 & $(+7.8)$ & 27 & 33 & $(+22.2)$ & 27 & 38.5 & $(+42.6)$ \\
\hline SD & 0.3 & 4.3 & & 1.4 & 1.0 & & 0.7 & 2.5 & \\
\hline
\end{tabular}

Table 2. Effect of infecting Biomphalaria alexandrina snails with Bacillus thuringiensis kurstaki before Schistosoma mansoni miracidial exposure on infection and intramolluscan development of the parasite in three successive generations

\begin{tabular}{|ccccccccccc|}
\hline & \multicolumn{3}{c}{ First generation } & \multicolumn{2}{c}{ Second generation } & \multicolumn{3}{c|}{ Third generation } \\
\cline { 2 - 9 } Parameter & Control $\begin{array}{c}\text { infected } \\
\text { with } \\
\text { bacteria }\end{array}$ & $\begin{array}{c}\text { \% of } \\
\text { change }\end{array}$ & Control $\begin{array}{c}\text { infected } \\
\text { with } \\
\text { bacteria }\end{array}$ & $\begin{array}{c}\% \text { of } \\
\text { change }\end{array}$ & $\begin{array}{c}\text { Control } \\
\text { infected } \\
\text { with } \\
\text { bacteria }\end{array}$ & $\begin{array}{c}\% \text { of } \\
\text { change }\end{array}$ \\
\hline $\begin{array}{c}\text { Number of } \\
\text { exposed snails }\end{array}$ & 25 & 25 & & 50 & 50 & 30 & 30 & \\
$\%$ of Infection & 90 & 40 & $(-55.5)$ & 92 & 16 & $(-82.6)$ & 90 & 73.7 & $(-18.1)$ \\
$\begin{array}{c}\text { Mean prepatent } \\
\text { period (days) }\end{array}$ & 27 & 32 & $(+18.5)$ & 27 & 32 & $(+18.5)$ & 27 & 35 & $(+29.6)$ \\
SD & 0.3 & 1 & & 1.4 & 2.3 & & 0.7 & 2.8 & \\
\hline
\end{tabular}

Arab Univ. J. Agric. Sci., 13(2), 2005 
Table 3. Effect of infecting Biomphalaria alexandrina snails with Bacillus thuringiensis kurstaki after Schistosoma mansoni miracidial exposure on worm recovery of the parasite in three successive generations

\begin{tabular}{|ccccc|}
\hline Worm sex & Control & $1^{\text {st }}$ generation & $2^{\text {nd }}$ generation & $3^{\text {rd }}$ generation \\
\cline { 2 - 5 } & $\begin{array}{c}\text { Mean number of } \\
\text { recovered }\end{array}$ & $\begin{array}{c}\text { \% reduction of } \\
\text { recovered } \\
\text { worms }\end{array}$ & $\begin{array}{c}\% \text { reduction of } \\
\text { recovered } \\
\text { worms }\end{array}$ & $\begin{array}{c}\% \text { reduction of } \\
\text { recovered } \\
\text { worms }\end{array}$ \\
\hline Female & 38.7 & 48.3 & 76.7 & 70.3 \\
Male & 44.6 & 55.2 & 79.8 & 48.4 \\
Total & 83.3 & 52 & 78.4 & 58.6 \\
\hline
\end{tabular}

Table 4. Effect of infecting Biomphalaria alexandrina snails with Bacillus thuringiensis kurstaki before Schistosoma mansoni miracidial exposure on worm recovery of the parasite in three successive generations

\begin{tabular}{|c|c|c|c|c|}
\hline & Control & $1^{\text {st }}$ generation & $2^{\text {nd }}$ generation & $3^{\text {rd }}$ generation \\
\hline Worm sex & $\begin{array}{c}\text { Mean number of } \\
\text { recovered } \\
\text { worms/mous }\end{array}$ & $\begin{array}{l}\% \text { reduction of } \\
\text { recovered } \\
\text { worms }\end{array}$ & $\begin{array}{l}\% \text { reduction of } \\
\text { recovered } \\
\text { worms }\end{array}$ & $\begin{array}{l}\% \text { reduction of } \\
\text { recovered } \\
\text { worms }\end{array}$ \\
\hline Female & 38.7 & 27.7 & 71.6 & 76 \\
\hline Male & 44.6 & 41 & 75.3 & 70.2 \\
\hline Total & 83.3 & 34.8 & 73.6 & 72.9 \\
\hline
\end{tabular}


lethal effects (Ducklow et al 1979; Cheng, 1986; El Emam et al 1996). The present commercial Bacillus bacteria, $B$. thuringiensis kurstaki, is commenly used in Egypt as a biocontrol agent in the combat against the bollworms Pectinophora gossypiella and Earias insulana (El-Gemeiy et al 1999; El-Gemeiy, 2001). It had been tested for molluscicidal effect on B.alexandrina snails, specially on hatchability of eggs, survival and growth of snails by Gamal et $\boldsymbol{a l}$ (2000).

In the present work, this bacteria was used for the first time to test its effect on $S$. mansoni infection of $B$. alexandrina and on the development of the parasite. This investigation aimed also to elucidate whether this effect is extended to successive generations of the parasite in both snails and mice. Information obtained from this study should help in evaluating potential effect of this bacteria on transmission of schistosomiasis.

The results indicated that infection of snails with this bacteria in both cases showed a deleterious effect on the life cycle of the parasite by reducing the infection rate of snails, delaying the intramolluscan development as well as reducing the worm recovery in the final host (mice). This effect was clear in the three successive generations of the parasite. The present findings are different from the results of El Emam et al (1996) and El Emam \& Haroun, (1999) who worked on another strain of Bacillus namely $B$. thuringiensis israelensis. The former authores observed that the cercarial production of infected $B$. alexandrina was suppressed to minimal after two weeks of bacterial infection, while the later authors claimed that the bacteria did not exhibit any significant effect on cer- carial production and duration of cercarial shedding. The difference in results between the present and other works may be attributed to strain difference of the bacteria used in both cases, being kuristaki in the present work and israelensis in their work. B. thuringiensis israelensis is known to be a mosquito larvicide (De Bargae, 1978; Bekheit, 1984).

The possible use of bacteria as a biocontrol agent against schistosomiasis vector snails was suggested by several investigators. Berry (1949) and Michelson (1957) observed a disease with high degree virulence against Australorbis glabratus, Physopsis africans and $B$. pfeifferi snails and added that this disease was due to a gram negative bacterium. Most work on effect of bacteria on medically important snails were carried out on Bacillus pinottii. Thus, this bacteria was used in laboratory and field trial to control $A$. glabratus in Venzuella (Textra \& Scorza, 1954) and in Egypt, (Dias \& Dawood, 1955). The latter authors added that this bacteria is harmless to vertebrates. Later on, Ducklow et al (1979) and Cheng (1986) recorded in wild and laboratory populations of $B$. glabrata snails several pathogenic bacterial genera.

In conclusion, the present effect of $B$. thuringiensis kurstaki on schistosomiasis transmission may add to its larvicidal potency against the cotton bollworms.

\section{REFERENCES}

Barlow, C.H. and H. Munech (1951). Life span and monthly mortality rate of Bulinus truncatus and Planorbis boissyi the intermediate hosts of schistosomiasis in Egypt. J. Parasitol., 37 : 165-173.

Bekheit, S.S. (1984). Laboratory trials with Bacillus thuringiensis serotype H-14 
in controlling mosquito larvae. J. Egypy. Soc. Parasitol. 14 : 71-76.

Berry, E.G. (1949). A recently observed snail disease. Ann. Rep. Am. Malacol. Union News Bull. 49 : 10-11.

Cheng, T.C. (1986). Biological control studies, bacteria associated with moribund Biomphalaria glabrata mollusca in the laboratory. J. Invert. Pathol., 47(2): 219-224.

De Bargae, H. (1978). A new strain of Bacillus thuringiensis var. israelensis serotype H-14. C.R. Acad. Sci. Paris t. 286: 797-800.

Dias, E. and M.M. Dawood (1955). Preliminary trials on the biological snail control with Bacillus pinottii in Egypt. Med. Inst. Osw. Cruz., 53: 13-29.

Ducklow, H.W.; P.J. Boyle; P.W. Maugel; C. Strong and R. Mitchell (1979). Bacterial flora of schistosome vector snail Biomphalaria glabrata. Appl. Env. Microbiol., 38(4): 667-672.

Ducklow, H.W.; H.M. Tarraza Jr. and R. Mitchell (1980). Experimental bathogenicity of Vibrio parahaemolyticus for the schistosome -bearing snail Biomphalaria glabrata. Can. J. Microbiol., 26(4): 503-506.

Ducklow, H.W.; K. Chausen and R. Mitchell (1981). Ecology of bacterial communities in the schistosomiasis vector snail Biomphalaria glabrata. Microb. Ecol., 7 (3): 253-274.

El-Emam, M.A. and N.H. Haroun (1999). Effect of Bacillus thuringiensis israelensis bacteria as a biocontrol agent on Bulinus truncatus snails and their susceptibility to Schistosoma heamatobium infection. Egypt. J. Appl. Sci., 14(1): 350-360.

El-Emam, M.A.; S. El Hak and M. Shafik (1996). Prelimenary studies on Bacillus thuringiensis israelensis bacteria as a biocontrol agent against Biomphalaria alexandrina snails. Egypt. J. Appl. Sci., 11 (9): 184-191.

El-Gemeiy, Hayat M. (2001). Efficacy of different Bacillus thuringiensis formulations against the pink bollworm Pectinophora gossypiella (Saund.). J. Agric. Sci. Mansoura Univ., 26(1): 439-444.

El-Gemeiy, Hayat M.; Sonia M. Naguib; M.A.M. Shalaby and Magda E. Wahba (1999). Efficacy evaluation of the biocid Ecotech pro and the organophosphorus insecticide isometaphos for controlling the bollworms, Pectinophora gossypiella (Saund.) and Earias insulana (Boisd.). Annals Agric. Sci. Moshtohor 37(1): 673-684.

Gamal, Rawia F.; Meneret Z. Roshdy; S.M. Hafez and Menerva M. Tadros (2000). The molluscicidal activity of some local bacteria isolates and commercial Bacillus thuringiensis strains on: hatchability, mortality and growth rate of Biomphalaria alexandrina snails. J. Environment. Sci. 1 (2): 637-718.

Heynman, D. (1978). Man-made lakes and schistosomiasis. Proc. Inter. Conference on Schistosomiasis, Oct. 18-25 (1975). The Ministry of Health, Cairo, Egypt.

Larget, I. and H. Barjac (1981). Specificity and active principle of Bacillus thuringiensis var. israelensis (Article in French). Bull. Soc. Pathol. Exot. Filiales. 74(2): 216-227.

Liang, Y.S. (1974). Cultivation of Bulinus physopsis globosus (Morelet) and Biomphalaria pfeifferi (Krauss), snail hosts of schistosomiasis. Sterkiana 53 and 54: 7-52 and 1-27.

Madsen, H. (1992). Interspecific competition between Helisoma duryi (Wetherby, 1879) and intermediate hosts of schistosomiasis (Gastropoda: Planor- 
bidae).An evaluation of biological control of schistosome intermediate hosts by competitor snails. Danish Bilharziasis Laboratory,: 63-67.

Michelson, E.H. (1957). Studies on the biological control of schistosome - bearing snails, predators and parasites of fresh water mollusca. A Review Literature, Parasitol. 47: 413-426.

Osman, G.Y.; A.M. Mohamed and K. Jamel Al-Layl (1992). Studies on molluscicidal activity of different preparations of Bacillus thuringiensis as biological agents on Biomphalaria alexandrina snails as vectors of schistosomiasis (bilharziasis) in Saudi Arabia. Anzeiger fur Schadlingskunde, Pflanzenschutz, Unweltschutz. 65(4): 67-70.

Prah, S.K. and C. James (1977). The influence of physical factors on the behaviour and infectivity of micacidia of
Schistosoma mansoni and Schistosoma haematobium. II. Effect of temperature and ultraviolet light. J. Helminth., 51: 73-85.

Shiff, C.J. (1961). Trials with a new molluscicides, Bayer 73. in Southern Rhodesia. Bull. WHO 25 : 533-542.

Singer, S.; T.B. Bair; T.B. Hammill; A.M. Berte; M.M. Correa-Ochoa and A.D. Stambaigh (1994). Fermentation and toxin studies of the molluscicidal strains of Bacillus brevis. J. Ind. Microbiol., 13 (2): 112-119.

Textra, D.A. and J.V. Scorza (1954). Investigations sobre una farma bacteriana parecida al Bacillus binottii hallada en Venzuella con occion patogena sobre el Australorbis glabratus Say. Arch. Venzol. Pathol. Trop. Parasitol. Med. 2:235242. 
بحلة اتحاد الجحامعات العربية للدراسات والبحوث الزراعية ، جامعة عين شثس ، القاهرة ، 13(2) ، 559 - 568 ، 2005

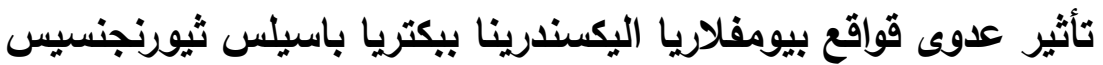
كيورستاكي علي ثلاثة أجيال متتالية من دودة شيستوسوما مانسوني

[37]

$$
\begin{aligned}
& \text { سامية البرديسي } 1 \text { - منيرفا تادرس } 1 \text { - شريف حافظ2 } \\
& \text { 1- معهد تيودور بلهارس للأبحاث - إمبابة - الجيزة - مصر }
\end{aligned}
$$

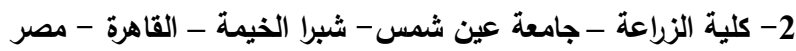

حضانة الطفيلي في القوقع فقد زادت ، حيث

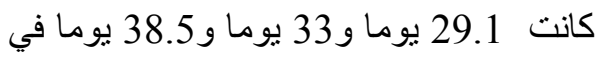
المنوسط ، بينما كانت في مجموعة المقارنة 27 يوما. وقد لوحظ انخفاض أعداد ديدان الطفيلي المستخلصة من الفئر ان المعدية بنسب 52\% و 58.48\% و58.4\% و58.6\% للأجيال الثلاثة علي الترتيب.

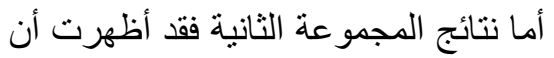

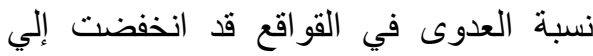

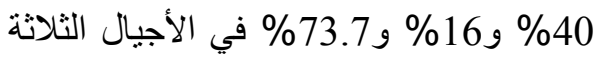
للطفيلي علي التوالي. وزادت فترة ولت وضانة الطفيلي داخل القواقع لتصبح 32 يوما و ولتون يوما و35 بوما في المتوسط علي الترنيب،

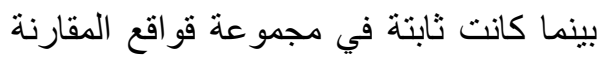
عند 27 يوما. أما أعداد ديدان الأجيال الثناثة للطفيلي داخل الفئران فقد أظهرت أندان الخفاضا

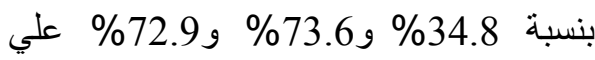

درس تأثير بكتيريا Bacillus thuringiensis kurstaki البلهارسيا المعوية شيستوسوما مانسوني الئي

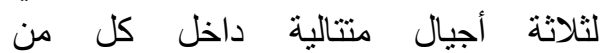

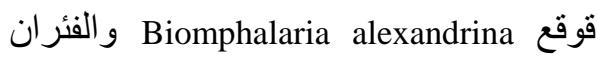
البيضاء، فقد استخدم تركيز الجرعة تحت

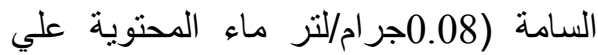

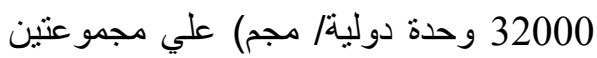
من القواقع: حيث عوملت المجموعة الأولي دولي

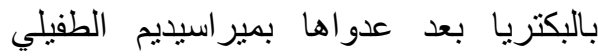

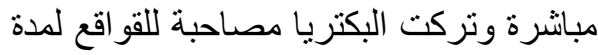

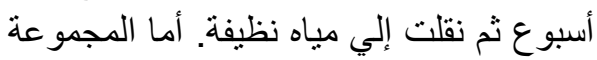

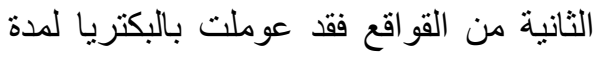

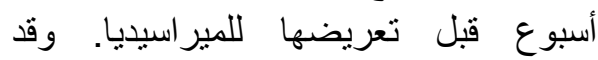

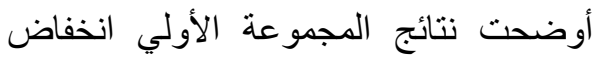
نسبة العدوى في القواقع للأجيال الثلاثة

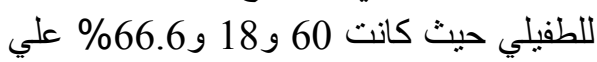

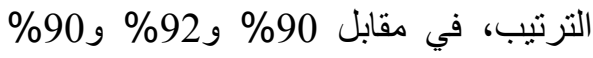
في القواقع غير المعاملة بالبكتريا. أما فترة 
انتقـال طفيلـي شيستوسـو ما مانسـوني لثناتــة

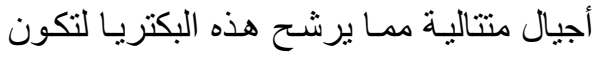

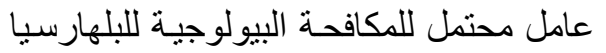
المعوية.

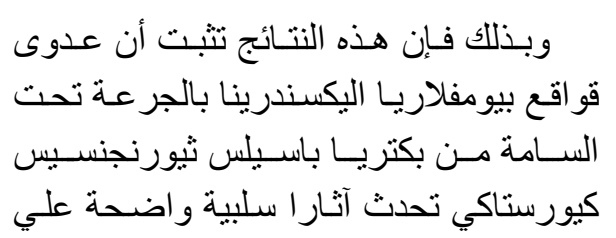

تحكيم: أ.د راوية فتحى جمال

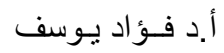

